\title{
A PRELIMINARY PHYSICO CHEMICAL ASSAY OF GOKSURA GRANULES - A PILOT STUDY
}

\author{
Thirunavukkarasu MS*, Galib ${ }^{1}$, Shukla VJ², Harisha $\mathrm{CR}^{3}$, Thakar $\mathrm{AB}^{4}$, Baghel MS \\ ${ }^{1}$ Lecturer, Department of Rasa Shastra, IPGT\&RA, GAU, (galib14@yahoo.co.in) \\ ${ }^{2}$ Head, Department of Pharmaceutical Chemistry IPGT\&RA, GAU, (drvivekshukla@yahoo.co.in) \\ ${ }^{3}$ Head, Department of Pharmacognosy, IPGT\&RA, GAU, (harishkumar33@ymail.com) \\ ${ }^{4}$ Reader, Department of Panchakarma, IPGT\&RA, GAU, (anup_thakar@yahoo.com) \\ ${ }^{5}$ Director, IPGT\&RA, Gujarat Ayurved University, Jamnagar, (baghelayu@rediffmail.com)
}

\begin{abstract}
Tribulus terrestris (Linn) of Zygophyllaceae family commonly known as Goksura is used in Ayurvedic system of medicine. It is distributed through out tropical and warm temperate regions of the world. Commonly it is known as Caltrops, Puncture vine. The Fruits of Goksura are considered as Diuretic, Aphrodisiac; used in Urolithiasis, Sexual dysfunctions and Infertility. As the powder is not palatable, its form has been converted in to granules form and attempts were made to evaluate its physico chemical profile. Pharmacognostically authenticated Tribulus terrestris was used for the preparation of granules and it was analyzed through qualitative and quantitative analysis of Physico - chemical parameters. Fingerprints of Thin Layer Chromatography (TLC) and High-Performance Thin Layer chromatography study (HPTLC) were also developed.
\end{abstract}

Keyword: Tribulus terrestris, Zygophyllaceae, Goksura, Phytochemical Analysis, Chromatography, Ayurveda.

\section{Introduction:}

In the description of Shodasakala

Chikitsa (1) (Sixteen Pre-requisite Qualities), Ayurvedic classics have given special importance to the Physician's ability to understand the rationale behind the utility of natural components in modifying the disease conditions and in reestablishing the equilibrium of Doshas (Humour), Dhatus (Tissues) and Mala's (Waste Products) or in other words, maintaining the Health.

Acharya Charaka, explained
Goksura under Madhuraskandha dravya(2) (Group of drugs possessing sweet taste), Mutravirechana gana (Group of drugs with Diuretic properties), Svayathuhara gana (Group of drugs with Anti inflammatory properties) and

\footnotetext{
* Corresponding Author:

PhD Scholar, Department of Kayachikitsa,

IPGT\&RA, Gujarat Ayurved University, Jamnagar

E-mail ID: ayurthiru@yahoo.co.in
}

Anuvasanopaga gana(3) (Group of drugs used in preparation of unctuous enema), where as Acharya Susruta included this drug under Vidarigandhadi gana, Virataruvadi gana(4) (Group of drug commencing from Vidarigandha and Virataruvadi), and Kantak panchamula(5) (Group of five thorny drugs whose roots are used).

Tribulus

terrestris

(Zygophyllaceae) is a procumbent annual or perennial herb with many spreading slender branches, the immature portions covered in a fine silky hair.(6) It is commonly known as Caltrops, Puncture vine and it is distributed through out tropical and warm temperate regions of the world. (7)

Literature survey reveals the presence of Chlorogenin, diosgenin and its acetate, gitogenin, astragalin, dioscin, gracillin, hecogenin, ruscogenin, trillin, furostanol glycoside, spirosterol saponin and a dihydroxy spirosteroidal sapogenin, 
trigogenin-3-diglucorhamnoside

(terrestroside F), saponins $\mathrm{C} \& \mathrm{G}$, kaempferol, kaempferol-3-glucoside, kaempferol-3-rutinoside, kaempferol-3- $\beta$ D- (6"-p-coumaroyl) - glucoside, glucose, rhamnose, rutin, harmine, neogitogenin, quercetin, reducing sugars, campesterol, $\beta$ sitosterol, stigmasterol, amino acids, alkaloids harmine, harmaline, harman and tetrahydroharmine; neotigogenin, amino acids (root), Tigogenin, Hecogenin and Gitogenin in hydrolysed extracts of fruits, roots and leaves.(8) Fruits of Goksura are used as Diuretic(9), Aphrodisiac(10) and indicated in Urolithiasis(11), Sexual dysfunction as well as Infertility(12).

In the description of Chatuspada (Four Limbs of Treatment), Drugs have the second most importance in treating the diseases and also the drug should possess the good qualities in it(13). So, proper identification and standardization of the drug is essential. Each and every drug has its own physical and chemical characteristics that help for separating it from other closely related drugs. Hence physicochemical studies of a particular drug by making use of various parameters help in standardizing the drug and validate it. Chromatographic techniques were adopted for the separation of active moieties present in the formulation. Therefore, an attempt has been made to standardize Goksura granules, an Ayurvedic medicine based on their TLC and HPTLC fingerprint profile.

\section{Aims \& objectives:}

1. Pharmacognostical Study of powdered drug - Fruits of Goksura

2. Physico-chemical analysis of Goksura Granules

\section{Method of preparation of the Goksura Granules}

The dried fruits of Goksura were subjected to pulverizer to get fine powder. Equal quantity of sugar was taken and syrup was prepared by adding sufficient quantity of water in mild flame with constant stirring till syrup reaches the Tantumathvam (thread like) stage. Then Goksura powder was added to the sugar syrup and mixed thoroughly to prepare a homogeneous blend. The blended mass was sieved through a $40 \#$ sieve to obtain granule form and kept it for drying in room temperature.

\section{Materials \& methods:}

Plant Material: The dried fruits of Tribulus terrestris were collected from the Pharmacy, Gujarat Ayurved University, Jamnagar. The fruits were pulverized and sieved through \# 80 and fine powder was collected. The powder was subjected to powder microscopy.

\section{Pharmacognostical}

Study:

Morphological, Organoleptic and Microscopic study of the powdered drug was done as per the guidelines of Ayurvedic pharmacopoeia of India(6) at Department of Pharmacognosy, I.P.G.T \& R.A, Jamnagar.

The powder was converted in to granules at the Pharmacy, Gujarat Ayurved University, Jamnagar.

Physico - chemical study: Goksura granules were analyzed by using, qualitative and quantitative parameters at Pharmaceutical Chemistry Laboratory of I. P. G.T \& R. A., Gujarat Ayurved University, Jamnagar.

\section{RESULTS \& DISCUSSION:}

\section{Pharmacognostical Study:}

Organoleptic characters: The powder was greenish yellow in color, has pleasant odor and sweet and bitter in taste.

Powder Microscopy: The dried powder was mounted in the distilled water to detect the unicellular Trichomes, Starch grains, Stratified Fibers, Oil globules, Prismatic crystals of calcium oxalate. When stained with Phloroglucinol and Conc. Hcl, Lignified cells with polygonal cells of mesocarp cells, Lignified Parenchyma, Stone cells were observed. 
(Plate No. 1). All the microscopic characteristics identified were equivalent

Physico - chemical Study:

Organoleptic Characters: The characters of the sample are tabulated in table no. 2

Physico-chemical parameters: The granules were evaluated for physico chemical parameters like Total Ash Value, loss on drying, $\mathrm{pH}$ value, Sugar estimation (Total sugar, Reducing Sugar, Non Reducing Sugar), Acid soluble and watersoluble extractive values. The results were placed at table no. 3

The Common parameters mentioned for Goksura in Ayurvedic Pharmacopoeia of India are total ash, $\mathrm{pH}$ Value, water and alcohol soluble extractives (6). On its basis the parameters like total ash content, water and methanol soluble extractives etc., were selected. Presence of more moisture content in a sample can create preservation problem. Hence loss on drying was also selected as one of parameters. Since, the sample was in the form of granules has the possibility of containing significant quantity of sugar, hence Sugar estimation was considered as another parameter. Total sugar was found to be $50.73 \% \mathrm{w} / \mathrm{w}$ suggesting presence of considerable amount of sugar in the sample. The water-soluble extractive and methanol soluble extractive values were found to be $51.6 \%$ and $27 \%$ respectively, indicating considerable amount of polar compounds in the sample.

Qualitative Test of Goksura Granules: The methanol extract of the sample was analyzed qualitatively for different functional groups. Details are placed at table no. 4 .

\section{Thin layer chromatography: Methanol Extract:}

Granules weighing $5 \mathrm{gm}$ are taken with $100 \mathrm{ml}$ of alcohol kept for twentyfour hours. Filtrate was prepared and evaporated till it gets dried in a flat- to the standard profile. (6)

bottomed shallow dish and concentrated on water bath to volume of requirement.

TLC is mentioned as a primary tool for identification as part of monographs on all medicinal plants. (14) Alkaloid fraction was used for the spotting of the TLC plate (Silica gel G Precoated plates). Then the spotted TLC was run with the solvent systems (Toluene $(8 \mathrm{ml})$, Ethyl acetate (2 $\mathrm{ml})$, Glacial acetic acid $(0.5 \mathrm{ml}))$ separately. And the resulting TLC pattern was viewed under long wave ultra violet light at $366 \mathrm{~nm}$ or Short wave ultra violet light at $254 \mathrm{~nm}$ (Table no.5). Then after spraying with the Anisaldehyde Sulphuric acid reagents and drying in a hot air oven and the number of spots viewed under daylight (Table no.6). (Plate No.2)

TLC of alcoholic extract of drug on silica get "G" plate using Toluene $(8 \mathrm{ml})$ : Ethyl acetate $(2 \mathrm{ml})$ : Glacial acetic acid $(0.5 \mathrm{ml})$ shows five spots Under $366 \mathrm{~nm}$ U.V. at hRf 15, 43, 50, 72 and 97. Where as in $254 \mathrm{~nm}$ three zones visible at hRf 15, 72 , 97. On running mobile phase over stationary phase, well distributed, distinct, clear spots were observed without clumping.

Thin Layer Chromatography of alcoholic extract of Goksura Granules after spraying Anisaldehyde Sulphuric acid followed by heating and then visualized in day light shows 7 prominent spots at hRf 22, 40, 54, 65, 77, 86, 97

\section{High Performance Thin layer chromatography: \\ Methanol extract of Goksura} Granules were spotted on precoated silica gel GF 60254 aluminium plate as $5 \mathrm{~mm}$ bands, $5 \mathrm{~mm}$ apart and $1 \mathrm{~cm}$ from the edge of the plates, by means of a Camag Linomate $\mathrm{V}$ sample applicator fitted with a $100 \mu \mathrm{L}$ Hamilton syringe. Toluene $(8 \mathrm{ml})$, Ethyl acetate $(2 \mathrm{ml})$, Glacial acetic acid $(0.5 \mathrm{ml})(\mathrm{v} / \mathrm{v})(20 \mathrm{ml})$ was used as a mobile phase. The development distance was 6.4 
$\mathrm{cm}$ (development time $30 \mathrm{~min}$. .). After development, Densitometric scanning was performed with a Camag T.L.C. scanner III in reflectance absorbance mode at 254 $\mathrm{nm}$ and $366 \mathrm{~nm}$ under control of win CATS software (V 1.2.1 Camag) (Fig No.1). The slit dimensions were $6 \mathrm{~mm} \mathrm{x}$ $0.45 \mathrm{~mm}$ and the scanning speed was 20 mm s-1 (Table no.7). Then the plate was sprayed with Anisaldehyde Sulphuric acid followed by heating and then visualized in day light shows 4 prominent spots (Table no. 8).

Visual observation under UV showed multiple spots, but on analyzing under densitometer all the spots were not detected. This may be due to the limitations of the integrative system Savitsky - Golay 7 with following specifications like Slope - 5; Minimum height - 10AU; Minimum area - $50 \mathrm{AU}$ and Maximum height was 990 AU. However, chromatogram shows 7 prominent spots at hRf $3,16,42,61,68$, 84,98 in short wave uv $254 \mathrm{~nm}$ and 2 prominent spots at hRf 3,98 in long wave uv $356 \mathrm{~nm}$

HPTLC of Methanolic extract of Goksura Granules after spraying Anisaldehyde Sulphuric acid followed by heating and then visualized in day light shows 4 prominent spots at hRf $3,46,71$, 78 .

\section{CONCLUSION:}

The plant Tribulus terrestris is used from the ancient time for its medicinal values and most of the Ayurvedic formulations prescribed for various diseases have Goksura as one of the ingredients. Most of the formulations are clinically effective but cumbersome for the patient compliance. In the present study, the granule form was evaluated for pharmaceutical feasibility and for patient palatability.

\footnotetext{
The plant Tribulus terrestris was identified and authenticated
}

phamacognostically and was used as a unique ingredient. The formulation namely, Goksura Granules were subjected to phytochemical, physico-chemical, TLC and HPTLC studies. It is inferred that the formulation meets the minimum qualitative standards as reported in the API at a preliminary level.

On the basis of our observations and experimental results, we created method of preparation of Goksura granules for the first time and are economical in terms of time and machinery. This study may be used as reference standard in the further quality control researches. Further studies may be carried out based on identification and separation of active ingredients with the help of Biomarkers like Protodioscin.

\section{ACKNOWLEDGEMENTS}

The authors wish to thank Prajapati P.K, Director of Pharmacy, Department of Rasashastra, IPGT\&RA, Gujarat Ayurveda University, Jamnagar for his sincere guidance in the preparation of granule.

\section{REFERENCES:}

1. Agnivesa, Charaka Samhita, Acharya Jadavji Trikamji, 5th Edition, Choukambha publication, Varanasi, 2001; 64

2. Ibid; 284

3. Ibid; 33

4. Sushruta, Sushruta Samhita, Acharya Jadavji Trikamji, 8th edition, Chaukhambha orientalia, Varanasi, $2005 ; 164$

5. Ibid; 169.

6. Anonymous, The Ayurvedic Pharmacopoeia of India, Part- I, Vol I, 40, 1st Edition, 2001, Ministry of Health And Family Welfare, Department of AYUSH (Government of India).

7. Holm et al, The world's worst weeds: Distribution and biology. East-West Center/University Press of Hawaii. $1977 ; 467$ 
8. Data Base On Medicinal Plants Used In Ayurveda, Central Council For Research In Aurveda \& Siddha, Volume 3, New Delhi, 2002; 229

9. Al-Ali M, Wahbi S, Twaij H, Al-Badr A., Tribulus terrestris: preliminary study of its diuretic and contractile effects and comparison with Zea mays. J Ethnopharmacol 2003 Apr;8 $5(2-3): 257-60$

10. Ivan A. Ross, Medicinal Plants of World (2001), Ind.J.surg., 1976; 38, 12

11. Anand R et al, Activity of certain fractions of Tribulus terrestris fruits against experimentally induced urolithiasis in rats. Indian J Exp Biol. 1994 Aug; 32(8): 548-52.

12. Gauthaman K et al. "Aphrodisiac properties of Tribulus Terrestris extract (Protodioscin) in normal and castrated rats". Life Sciences. 71.12 (2002): 1385-96.

13. Agnivesa, Charaka Samhita, Acharya Jadavji Trikamji, Choukambha publication, Varanasi, 2001; 61

14. Eike Reich et al, TLC for the Analysis of Herbal Drugs - A Critical Review of the Status and Proposal for Improvement of Monographs, Scientific Note, Pharmeuropa 15.3, July 2003, 424-430. 
Table No.2 Organoleptic Parameters of Goksura Granules

\begin{tabular}{|c|l|l|}
\hline S.No & \multicolumn{1}{|c|}{ Parameters } & \multicolumn{1}{c|}{ Goksura Granules } \\
\hline 1 & Texture & Rough \\
\hline 2 & Color & Yellowish brown \\
\hline 3 & Taste & Sweet, Bitter \\
\hline 4 & Odor & Pleasant \\
\hline
\end{tabular}

Table No. 3 Physico-chemical parameters

\begin{tabular}{|c|l|l|}
\hline S. No. & \multicolumn{1}{|c|}{ Parameters } & \multicolumn{1}{c|}{ Sample - Goksura Granules } \\
\hline 1. & Loss on drying & $4.88 \% \mathrm{w} / \mathrm{w}$ \\
\hline 2. & Water soluble Extract & $51.6 \% \mathrm{w} / \mathrm{w}$ \\
\hline 3. & Alcohol soluble Extract & $27 \% \mathrm{w} / \mathrm{w}$ \\
\hline 4. & Total Ash & $8.4 \% \mathrm{w} / \mathrm{w}$ \\
\hline 5. & pH Value & 5.76 \\
\hline & Sugar Estimation & \\
\hline 6. & Total Sugar & $50.73 \% \mathrm{w} / \mathrm{w}$ \\
& Reducing Sugar & $11.53 \% \mathrm{w} / \mathrm{w}$ \\
& Non - Reducing Sugar & $39.2 \% \mathrm{w} / \mathrm{w}$ \\
\hline
\end{tabular}

Table No. 4 Functional Groups

\begin{tabular}{|c|l|l|l|}
\hline S.No & \multicolumn{1}{|c|}{ Test } & \multicolumn{1}{|c|}{ Reagents } & \multicolumn{1}{c|}{ Results } \\
\hline 1 & Carbohydrate & Molish's test & Positive \\
\hline 2 & Steroid & Libermann - Burchard test & Positive \\
\hline 3 & Saponin Glycosides & Foam Test & Positive \\
\hline 4 & Flavonoids & Lead acetate test & Positive \\
\hline \multirow{2}{*}{5} & \multirow{2}{*}{ Alkaloids } & Dragendroff's test & Positive \\
\cline { 3 - 4 } & & Wagner's test & Positive \\
\hline
\end{tabular}

Table No. 5 TLC of Methanol Extract of Goksura Granules

\begin{tabular}{|c|c|c|c|c|c|}
\hline Extract & Solvent System & Wavelength & $\begin{array}{c}\text { No. of } \\
\text { spots }\end{array}$ & hRf value & $\begin{array}{c}\text { Observation } \\
\text { under UV light }\end{array}$ \\
\hline Methanol & $\begin{array}{c}\text { Toluene }(8 \mathrm{ml}): \\
\text { Ethyl acetate } \\
\text { Extract }\end{array}$ & $366 \mathrm{~nm}):$ \\
$\begin{array}{c}\text { Glacial acetic } \\
\text { acid }(0.5 \mathrm{ml})\end{array}$ & $254 \mathrm{~nm}$ & 3 & $15,72,97$ & $\begin{array}{c}\text { Parrot Green, Sky } \\
\text { Blue, Red, Green, } \\
\text { Blue spots }\end{array}$ \\
\cline { 3 - 6 } & & $50,72,97$ & $\begin{array}{c}\text { Blue, Blue, Blue } \\
\text { spots }\end{array}$ \\
\hline
\end{tabular}


Table No. 6 TLC - After spraying with Anisaldehyde Sulphuric acid

\begin{tabular}{|c|c|c|c|c|c|}
\hline Extract & Solvent System & Spray & $\begin{array}{c}\text { No. of } \\
\text { spots }\end{array}$ & hRf value & $\begin{array}{c}\text { Observation } \\
\text { under Daylight }\end{array}$ \\
\hline & $\begin{array}{c}\text { Toluene }(8 \mathrm{ml}): \\
\text { Ethyl acetate } \\
(2 \mathrm{ml}):\end{array}$ \\
$\begin{array}{c}\text { Exthanol } \\
\text { Extract }\end{array}$ & $\begin{array}{c}\text { Anisaldehyde } \\
\text { Glacial acetic } \\
\text { acid }(0.5 \mathrm{ml})\end{array}$ & $\begin{array}{c}\text { Sulphuric acid } \\
\text { acid }\end{array}$ & 7 & $\begin{array}{c}22,40,54,65, \\
77,86, \\
97\end{array}$ & Dark Blue spots \\
\hline
\end{tabular}

Table No. 7 HPTLC of Methanol Extract of Goksura Granules

\begin{tabular}{|c|l|c|c|c|}
\hline Extract & \multicolumn{1}{|c|}{ Solvent System } & Wavelength & $\begin{array}{c}\text { No. of } \\
\text { spots }\end{array}$ & hRf value \\
\hline \multirow{2}{*}{$\begin{array}{c}\text { Methanol } \\
\text { Extract }\end{array}$} & $\begin{array}{l}\text { Toluene }(8 \mathrm{ml}): \\
\text { Ethyl acetate }(2 \mathrm{ml}):\end{array}$ & $366 \mathrm{~nm}$ & 2 & 3,98 \\
Glacial acetic acid $(0.5$ & ml) & $254 \mathrm{~nm}$ & 7 & $3,16,42,61,68,84$, \\
\cline { 2 - 5 } & & & \\
\hline
\end{tabular}

Table No. 8 HPTLC - After spraying with Anisaldehyde Sulphuric acid

\begin{tabular}{|c|c|c|c|c|}
\hline Extract & Solvent System & Spray & $\begin{array}{c}\text { No. of } \\
\text { spots }\end{array}$ & hRf value \\
\hline $\begin{array}{c}\text { Methanol } \\
\text { Extract }\end{array}$ & $\begin{array}{c}\text { Toluene }(8 \mathrm{ml}): \\
\text { Ethyl acetate }(2 \mathrm{ml}): \text { Glacial }\end{array}$ & $\begin{array}{c}\text { Anisaldehyde } \\
\text { Sulphuric acid } \\
(0.5 \mathrm{ml})\end{array}$ & 4 & $3,46,71,78$ \\
\hline
\end{tabular}




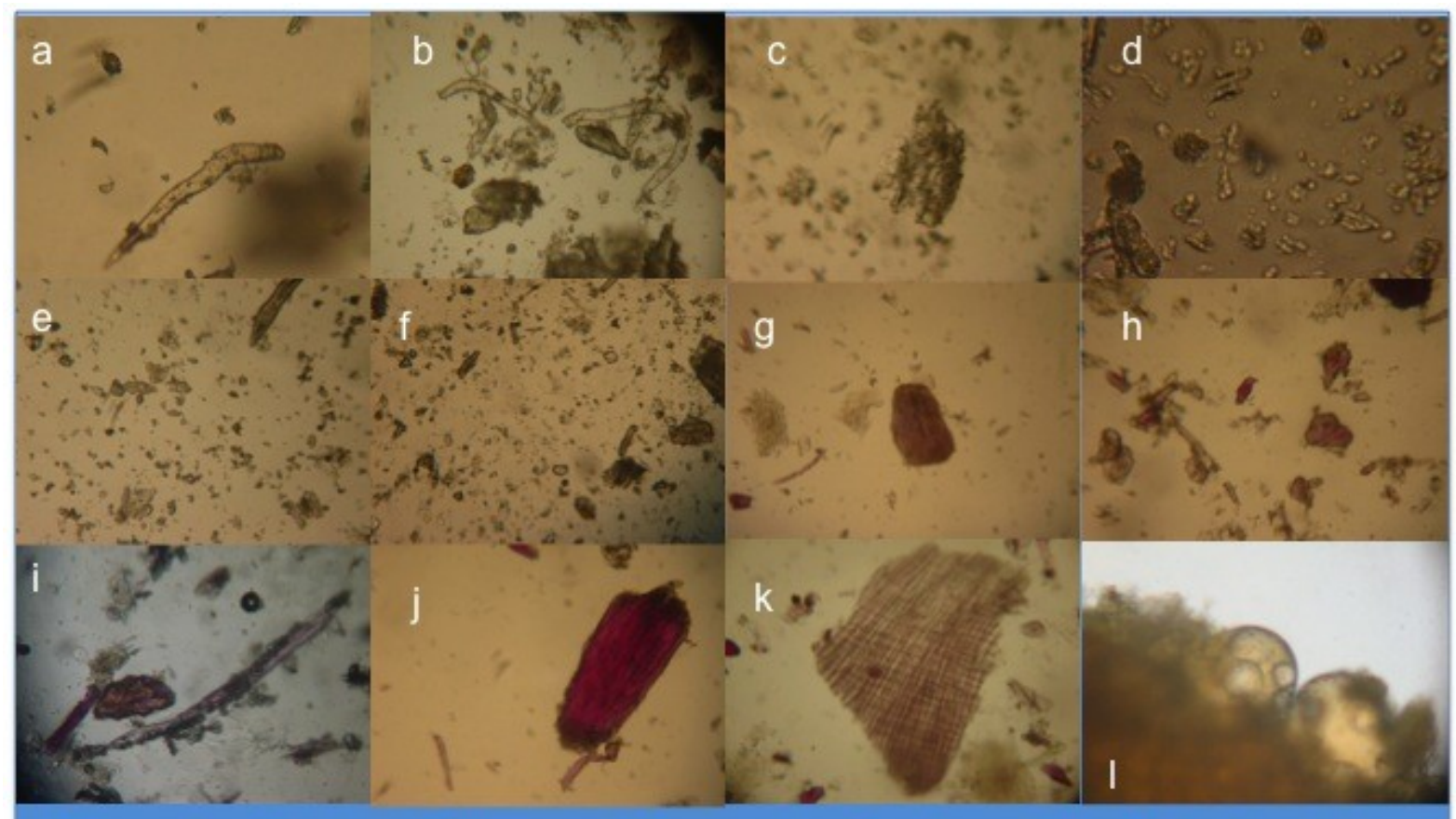

Plate no: 1 - a. Trichome, b.Trichome with Starch grain, c. Parenchymal cells, d. Rosette crystals, e. Starch grains, f. Prismatic crystals, g. Mesocarp cells, h. Stone cells, i. Fiber with stone cells, J. Lignified fibers, k. Lignified cells with polygonal cells of mesocarp, I. Oil globules.

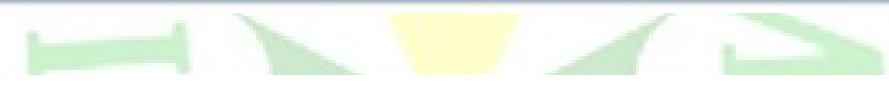

\section{Plate No:2 TLC of Goksura Granules}

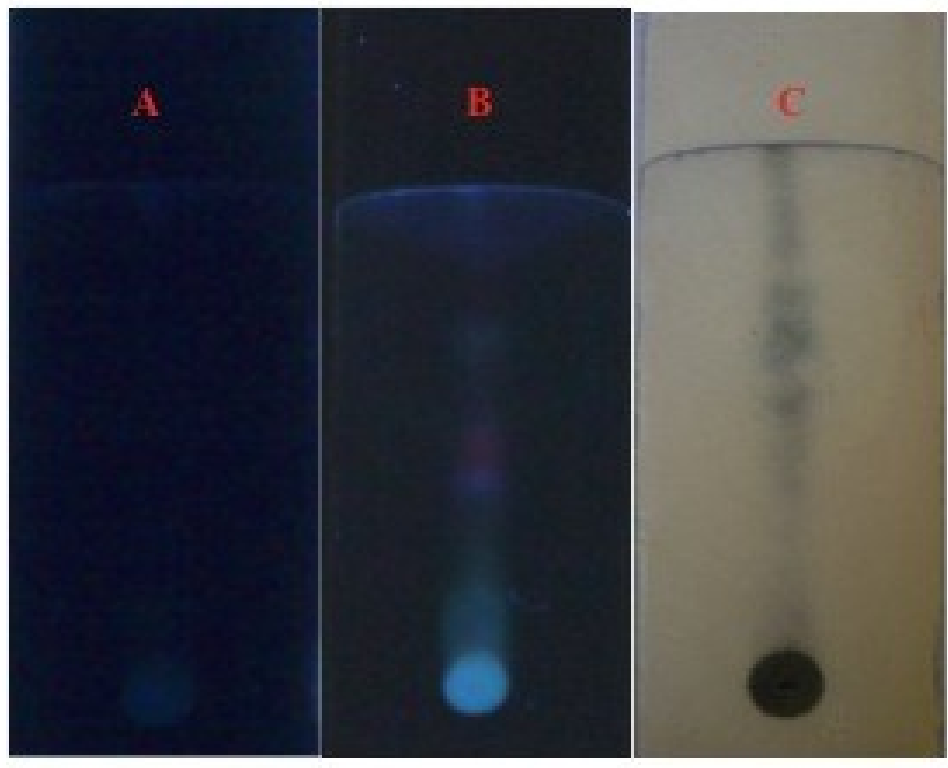
A. $254 \mathrm{~nm}$ UV light
B. $366 \mathrm{~nm}$ UV light
C. After spraying with Anisaldehyde Sulphuric acid 
Figure No.1 Densitogram curve of Goksura Granules Extract in $254 \mathrm{~nm}$ \& 366nm

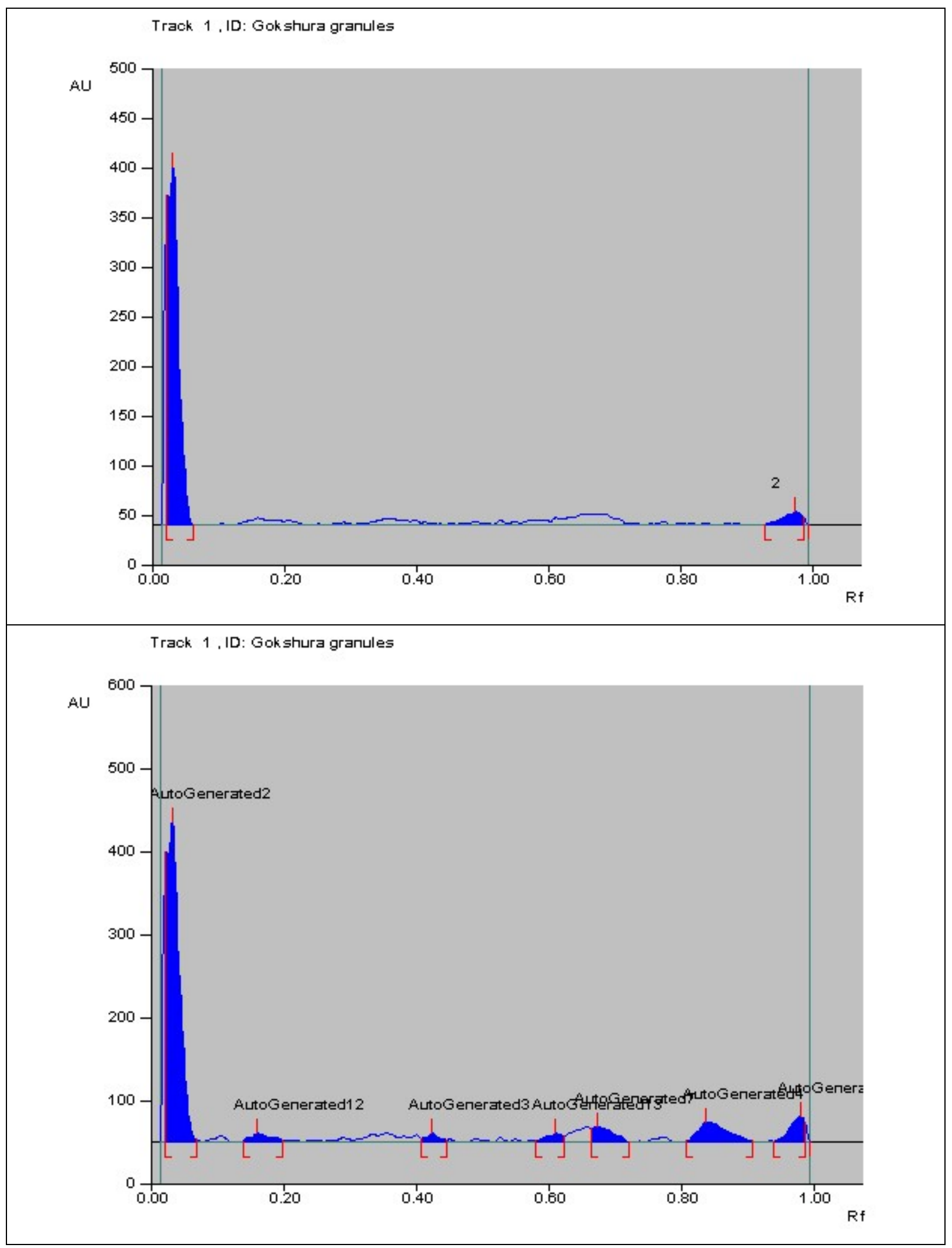

